\title{
Co-expression of candidate genes regulating growth perfor- mance and carcass traits of Barki lambs in Egypt
}

\author{
Nasser Ghanem ${ }^{1,2}$, Mohamed Zayed ${ }^{3}$, Ismail Mohamed ${ }^{4}$, Mona Mohammady ${ }^{35}$, M.F. Shehata ${ }^{6}$ \\ 1 Department of Animal Production, Faculty of Agriculture, Cairo University, El-Ga- \\ maa Street, 12613 Giza, Egypt; e-mail: nassergo@agr.cu.edu.eg \\ 2 Cairo University Research Park, Faculty of Agriculture, Cairo University, Egypt. \\ 3 Department of Animal and Poultry Breeding, Animal and Poultry Division, Desert Research Center, Cairo, \\ Egypt; e-mail: maz205@yahoo.com \\ 4 Department of Animal and Poultry Breeding, Animal and Poultry Division, Desert Research Center, Cairo, \\ Egypt; e-mail: ssmm ismail@yahoo.com \\ 5 Department of Animal and Poultry Breeding, Animal and Poultry Division, Desert Research Center, Cairo, \\ Egypt; e-mail: monamohammady@hotmail.com \\ 6 Department of Animal and Poultry Breeding, Animal and Poultry Division, Desert Research Center, Cairo, \\ Egypt; e-mail: mfaragdrc@yahoo.com \\ * Correspondence: e-mail : nassergo@agr.cu.edu.eg ; Tel.: +2023573966, Department of Animal Production, \\ Faculty of Agriculture, Cairo University, El-Gamaa Street, 12613 Giza, Egypt.
}

Simple Summary: There is an increasing demand for meat production as a main source of protein. In Egypt, the national production is still insufficient, creating a gap in the protein supply. Sheep are considered one of the main sources of protein from red meat. In addition, sheep have the ability to survive by grazing in the desert and consume low quality of forage. Individuals of the same breed vary in growth performance and final body weight. Thus, selecting sheep having fast growth and heavier body weight at the end of fattening period is crucial. Recent investigations revealed expression of candidate genes in various body tissues highlighting their role as molecular and biological marker of animal growth performance.

\begin{abstract}
The aim of present study was to link the gene expression profile of selected candidate genes with blood profile, growth performance and carcass traits of Barki lambs. Thirty-eight Barki lambs were divided into 3 groups (fast, intermediate and slow growing) according to growth performance. Body tissues (muscle, liver and fat) were taken from for RNA isolation and Real-time PCR. The results indicated that, the final body weight hot carcass weight were heavier $(P \leq 0.05)$ in fast $(49.9 \mathrm{Kg}$ and 24.57$)$ than intermediate $(40.7$ and $19.07 \mathrm{Kg}$ ) and slow (30.8 and $15.10 \mathrm{Kg}$ ) growing animals. The blood profile of total protein, total lipids, calcium, T3 and T4 hormones did not differ among sheep groups. Genes involved in protein biosynthesis (RPL7), fatty acid oxidation (CPT1) and lipolysis (FABP4) were up regulated in fast and intermediate growing lambs in all studied tissues. While, gene-regulating lipogenesis (ADIPOQ) was expressed similarly in fat and liver tissues, but increased its expression in muscle of fast and intermediate growing lambs. Expression of CAPN3 was increased in fast and intermediate growing compared to slow growing lambs. In conclusion, the current study providing an evidence for the importance of co-expression of these genes in main body tissues linked with growth performance of Barki lambs.
\end{abstract}

Keywords: Barki lambs; growth rate; carcass traits; gene expression. 


\section{Introduction}

Sheep are considered one of the main sources of animal protein. In addition, sheep have the ability to survive in the desert by grazing low quality forage [1]. Barki sheep are important genetic resources that raised under a transhumant animal farming system in the North Western coastal desert of Egypt with a population of 470,000 heads (11\% of the total Egyptian sheep population) and known to be well-adaptive to the harsh desert conditions [2]. Generally, sheep individuals of the same breed are varied in growth performance and final body weight at time of slaughter. Thus, selecting sheep individuals having faster growth rate and heavier body weight are crucial for meat production industry. Therefore, it is useful to apply the breeding program for meat production that target to select lambs that have greater average daily gain than other individuals in the same herd $[3,4]$.

Indeed, investigation of factors controlling sheep growth based on monitoring live body weights over a relevant time is of major interest among scientists and meat producers [4,5]. Moreover, determining which factors influence the growth curve supports management and improvement program of sheep breeding. The growth performance of farm animals is an important economic trait that regulated by genetic and non-genetic factors [6]. In addition, the growth performance of sheep is influenced by age of the dam, premating weight of the dam, type of birth, sex, breed and season of birth which all considered as non-genetic factors [7]. Taken into consideration that other factors such as slaughtering animals at immature body-weights, poor genetic potential of the local breeds and poor feeding conditions are major causes contributing of low meat production [8]. Therefore, it is required to get all information on growth rate and the maturity degree of live body weight relevant to carcass composition for genetic selection plan [9].

Understanding the genetic changes underlying phenotypic variation in domestic sheep (Ovis aries) may facilitate our efforts towards further improvement. Moreover, identification of genes underlying sheep growth performance would support worldwide efforts in increasing mutton production [10]. In this regard, gene expression profile was applied to detect growth performance of three Egyptian sheep breeds [11, 12]. However, there is no available data that linked expression profile and both growth and carcass traits of Egyptian sheep. Therefore, investigating the transcriptome profile of muscle tissues, especially with reference to transcription regulatory proteins, would provide useful information to improve the production and quality of sheep meat [13-14, 15]. Actually, muscle growth and development are regulated by core genes and signal transduction pathways [15-17]. Additionally, RPL7 was linked with pre-weaning gain in mutton merino [10, 14]. Genes regulating fatty acid uptake and metabolism such as FABP4 are usually considered as potential candidate genes for meat tenderness [18]. Therefore, the current research work aims to study the relationship of gene expression profile in major body tissues with growth performance, carcass traits and biochemical profile of Barki lambs. 


\section{Materials and Methods}

\subsection{Experimental Animals}

The current study was conducted on Barki sheep flock, belongs to Maryout Research Station, $35 \mathrm{~km}$ south of Alexandria, Desert Research Center, Ministry of Agriculture and Land Reclamation, Egypt. Thirty-eight Barki lambs were kept and fed individually after weaning at 3 months of age (Initial body weight) till to 12 months of age (Final body weight). The lambs were kept in a cubical cement box of dimensions (120 width*150 length*135 height $\mathrm{cm}$ ), and has access to water and ration. Lambs were fed as per standard schedule (NRC, 1985) to cover their nutritional requirements. Lambs were fed a certain amounts of commercial concentrate mixture (12\% crude protein) plus alfalfa hay (Trifolium alexandrinum). However, the amounts of concentrate feed mixture (CFM) offered to lambs were adjusted bi-weekly according to the live body weight changes. Moreover, water was available all the time for experimental animals.

\subsection{Experimental Design}

Lambs were weighed weekly after weaning and divided into 3 groups according to their growth rates (Fast, intermediate and slow growing). In addition, three samples of main body tissues (eye muscle, liver and fat tail) from three animlas representing each group were taken for gene expression profiling at the end of the fattening period (12 months of age). The genes selected in real-time PCR expression are regulators of different molecular pathways such as protein biosynthesis (RPL7), fat deposition or lipogenesis (ADIPOQ), fatty acid oxidation or lipolysis (CPT1 and FABP4) and muscle development (CAPN3).

\subsection{Slaughtering procedure and carcass trait}

Twenty-three lambs were slaughtered at 12 months of in meat processing unit at Maryout Research Station to evaluate carcass traits following the stranded protocol [19] lambs were fasted for approximately 24 hours before slaughtering. After slaughtering and bleeding, carcass were skinned and eviscerated before weighing. Weights of all non-carcass components (trachea, lungs, heart, liver, testes, spleen, kidneys, and kidney fat) were immediately weighed after removal from the body. The rumen and reticulum were cleaned and washed under cold running water, and then they were weighed. Empty body weights were recorded and all carcasses were held in a chiller at $4{ }^{\circ} \mathrm{C}$ for $24 \mathrm{~h}$ to evaluate cold carcass weight [19]. The Institutional Animal Care and Use Committee of Cairo University (CU-IACUC) has approved this study with approval number CU-II-F-8-20 on the first of February 2020. The project identification code is Agri-326, which was funded by The Science, Technology \& Innovation Funding Authority (STDF), Egypt.

\subsection{Blood and tissue sampling}

Nine blood samples (3 from each group) were collected during slaughtering in tubes that contain EDTA as anticoagulant substance. Tissue samples (liver, tail fat, and muscle) were taken immediately from lambs after slaughter and kept in RNA later then kept at $80^{\circ} \mathrm{C}$ till RNA extraction was performed in Cairo University Research Park, Faculty of Agriculture, Cairo University, Egypt.

\subsubsection{Analysis of blood T3 and T4 hormones profile}

Blood samples were collected in tubes containing EDTA as anticoagulant substance. Samples were centrifuged at $3000 \mathrm{rpm}$ for 20 minutes. Plasma was stored at $-20{ }^{\circ} \mathrm{C}$ until estimation of T3 and T4 hormones using an enzyme immunoassay test kit (Chemux Bioscience Inc, USA, CA). The sensitivity value reported to be according to manufacturer 
information. The intra and inter-assay variation coefficients were 5.0 and $13.0 \%$, respectively.

\subsubsection{Measurement of blood total protein level}

The profile total protein $(\mathrm{g} / \mathrm{dl})$ was done using colorimetric methods according to instructions provided by the manufacturer company (Bio diagnostic, Giza, Egypt). The plasma samples $(0.025 \mathrm{ml})$ were mixed well with biuret reagent $(1.0 \mathrm{ml})$ and incubated at $37^{\circ} \mathrm{C}$ for $10 \mathrm{~min}$ the absorbance for standard and samples were measured using the spectrophotometer at $550 \mathrm{~nm}$ wavelengths.

\subsubsection{Measurement of blood glucose concentration}

The blood glucose profile ( $\mathrm{mg} / \mathrm{dl})$ was measured using colorimetric methods according to instructions provided by the manufacturer company (Bio diagnostic, Giza, Egypt).

\subsubsection{Measurement of blood total lipids level}

The blood total lipids (mg/dl) was measured using colorimetric methods according to instructions provided by the manufacturer company (Bio diagnostic, Giza, Egypt).

\subsubsection{Measurement of blood calcium level}

The blood calcium level (mg/dl) was measured using colorimetric methods according to instructions provided by the manufacturer company (Bio diagnostic, Giza, Egypt).

\subsection{Gene expression Profile}

\subsubsection{Total RNA extraction}

The procedure of RNA isolation was performed using GeneJet RNA purification kit (Thermofisher Scientific, Vilnius, Lithuania) according to manufacture instructions. Approximately $20 \mathrm{mg}$ of tissue was weighed and grind with a pestle in a mortar using liquid nitrogen till powder was formed. The powder was transferred to a $1.5 \mathrm{ml}$ micro-centrifuge tube with $300 \mu$ lof lysis buffer and $20 \mu 1$ of $\beta$-mercaptoethanol and vortexed for 20 seconds. A volume of $600 \mu \mathrm{l}$ of diluted Proteinase K $(10 \mu \mathrm{l}$ of included Proteinase K diluted in $590 \mu \mathrm{l}$ of Tris-EDTA (TE) buffer) was added. It was vortexed for 20, incubated for 10 minutes at room temperature and it was centrifuged for 10 minutes at $12000 \mathrm{xg}$. $450 \mu \mathrm{l}$ of ethanol was added and mixed by pipetting. $700 \mu \mathrm{l}$ of lysate was transferred to the GeneJet RNA purification column and was inserted into a collection tube and then it was centrifuged for 1 minute at $12000 \mathrm{xg}$.

The flow through was discarded and placed the purification column in the tube. The previous step was repeated until all the lysate was transferred and centrifuged. The collection tube was discarded, which contained the flow though solution. The GeneJet RNA purification column was placed into a new $2 \mathrm{ml}$ collection tube. A volume of $700 \mu \mathrm{l}$ of wash buffer 1 was added to the GeneJet RNA purification column and centrifuged for 1 minute at $12000 \mathrm{xg}$. The flow through was discarded and the purification column was placed back into the collection tube, then $250 \mu \mathrm{l}$ of wash buffer 2 was added to the GeneJet RNA purification column and centrifuged at $12000 \mathrm{xg}$ for 2 minutes.

The collection tube containing the flow through solution was discarded and the GeneJet RNA purification column was transferred to a sterile $1.5 \mathrm{ml}$ RNase free microcentrifuge tube. Nuclease free water $(100 \mu \mathrm{l})$ was added to the GeneJet RNA purification columns and centrifuged at $12000 \mathrm{xg}$ for 1 minute. The purification column was discarded. For DNA digestion, $1 \mathrm{ml}$ of DNAse (Thermo Scientific, California, USA) was added to 9 $\mu \mathrm{l}$ of RNA sample and the mixture $(10 \mu \mathrm{l})$ was incubated in a thermal cycler for 30 minutes at $37^{\circ} \mathrm{C}$. After that, $1 \mathrm{ml}$ of EDTA was added to the mixture. The mixture (RNA, DNAse, and EDTA) was incubated in a thermal cycler (Thermofisher Scientific, CA, USA) for 10 minutes at $65^{\circ} \mathrm{C}$. Finally, the purity and concentration of extracted RNA were measured 
at A260/280 nm ratio (1.9-2.1) using NanoDrop 2000C (Thermofisher Scientific, Wilmington, DE, USA). The samples were stored at $-80^{\circ} \mathrm{C}$ freezer until cDNA synthesis.

\subsection{2. cDNA synthesis}

After adjusting the RNA concentration of all isolated RNA samples, synthesis of cDNA was done using revertAid First Strand cDNA Synthesis Kit (Thermofisher, USA). The reaction mix consisted of $1 \mu \mathrm{l}$ of oligo (dT) 18 primer to $11 \mu \mathrm{l}$ of the adjusted RNA, 4 $\mu \mathrm{l}$ of $5 \mathrm{x}$ reaction buffer, and $2 \mu \mathrm{l}$ of $10 \mathrm{mM}$ dNTP for each RNA sample. Finally, $1 \mu \mathrm{l}$ of RiboLock RNase inhibitor and $1 \mu$ l of revertaid reverse transcriptase was added to reach a final volume of $20 \mu \mathrm{l}$ and samples were incubated in a thermal cycler (Thermofisher Scientific, CA, USA) for 60 minutes at $42^{\circ} \mathrm{C}$ followed by $70^{\circ} \mathrm{C}$ for 5 minutes. The cDNA samples were stored in $-20^{\circ} \mathrm{C}$ freezer till used for real-time PCR runs.

\subsubsection{Quantitative Real-time PCR}

A pair of primers (forward and reverse) was designed for each specific gene (GAPDH, ADIPOQ, CPT1, FABP4, RPL7and CAPN3) using Primer3 software (http://primer3.wi.mit.edu//) as shown in Table 1. The design of primers was based on gene sequences described in the GenBank database (www.ncbi.nlm.nih.gov). Real-time PCR was performed using glyceraldehyde 3-phosphate dehydrogenase (GAPDH) as housekeeping gene The real-time PCR was done in the 96 well plate (Thermofisher Scientific, Wilmington, DE, USA). The real-time PCR reaction mix is composed of $2 \mu \mathrm{l}$ of cDNA sample, $12 \mu \mathrm{l}$ of Maxima SYBR Green/ROX qPCR Master Mix (Thermofisher Scientific, CA, USA), 0.2 $\mu 1$ of specific reverse primer, $0.2 \mu \mathrm{l}$ of specific forward primer and $7.6 \mu l$ of nuclease free water. Reaction was incubated in StepOnePlus ${ }^{\mathrm{TM}}$ Real-Time PCR (Applied Biosystems, CA, USA). The reaction mix was incubated at $50^{\circ} \mathrm{C}$ for 2 minutes; initial denaturation was done for 10 minutes at $95^{\circ} \mathrm{C}$ and 40 cycles at $95^{\circ} \mathrm{C}$ (Denaturation) for 15 minute and final step at $60^{\circ} \mathrm{C}$ for 1 minute (annealing), at $95^{\circ} \mathrm{C}$ for 15 seconds and then $60^{\circ} \mathrm{C}$ for 1 minute. The results were expressed as $\mathrm{Ct}$ values and relative gene expression profile was estimated delta delta $\mathrm{Ct}$ analysis (2- $\Delta \Delta \mathrm{CT}$ method) as done in our recent study (Ghanem et al., 2021).

\subsection{Statistical analysis}

The growth performance data and gene expression profile of the three different lambs of each experimental group (Fast, intermediate and slow growing animals) were analyzed using the procedure of General Linear Model (SAS, 2011). The statistical analysis was performed to test the effect of animal growth rate, carcass traits and biochemical measurements on gene expression profile of selected candidate transcripts by applying the following formula:

$$
Y i j=\mu+G i+e i j .
$$

$\mathrm{Y}$ ijk= individual observation; $\mu=$ Overall mean; $\mathrm{Gi}=$ Effect of growth rate; eij = Experimental error; $\mathrm{i}=1,2,3$ (fast, intermediate and slow).

The mean values were compared for statistical significance using Duncan's range test (1955). Differences were considered statistically significant at $\mathrm{P} \leq 0.05$.

\section{Results}

\subsection{Growth performance traits}

The birth weight of fast $(4.10 \mathrm{Kg})$ growing animals was similar of that of slow growing lambs $(2.82 \mathrm{Kg})$ however; both groups had heavier weight at birth than intermediated growing animals $(3.83 \mathrm{Kg})$. The least square means estimates of initial body weight, the final body weight, average daily gain and total body gain are shown in Table 2 . The initial body weight was significantly different $(\mathrm{P} \leq 0.05)$ in fast $(27.7 \mathrm{Kg})$, intermediate $(22.5 \mathrm{Kg})$ and slow growing lambs $(15.8 \mathrm{Kg})$. Accordingly, the final body weight was greater $(\mathrm{P} \leq$ $0.05)$ in fast $(49.9 \mathrm{Kg})$ and intermediate $(40.7 \mathrm{Kg})$ than slow growing animals $(30.8 \mathrm{Kg})$ as 
shown in Table 2 . The average daily gain was increased $(\mathrm{P} \leq 0.05)$ in fast $(173.6 \mathrm{gm})$ and intermediate $(112.0 \mathrm{gm})$ compared to slow growing animals (92.3 gm). Additionally, the total body gain was significant $(\mathrm{P} \leq 0.05)$ greater in fast $(22.3 \mathrm{Kg})$ and intermediate $(18.2$ $\mathrm{Kg})$ and slow growing animals $(15.0 \mathrm{Kg})$.

\subsection{Carcass traits}

The hot carcass weight (Table 3$)$ was increased $(P \leq 0.05)$ in fast and intermediate compared to slow growing lambs which recorded 24.57, 19.07 and $15.10 \mathrm{Kg}$, respectively. Moreover, a liver weight of slaughtered lambs (Table 3 ) was significantly increased ( $\mathrm{P} \leq$ $0.05)$ in fast $(0.62 \mathrm{Kg})$ compared to intermediate $(0.50 \mathrm{Kg})$ and slow growing lambs $(0.54$ $\mathrm{Kg})$. On the other hand, dressing percentage, non-carcass fat and tail fat were not significantly different among fast $(48.83 \mathrm{Kg}, 1.46 \mathrm{Kg}$ and $1.65 \mathrm{Kg})$, intermediate $(47.48 \mathrm{Kg}, 1.21$ $\mathrm{Kg}$ and $1.79 \mathrm{Kg}$ ) and slow growing lambs $(46.90 \mathrm{Kg}, 1.18 \mathrm{Kg}$ and $1.48 \mathrm{Kg})$. Furthermore, total body fat (non-carcass fat + tail fat $\mathrm{Kg}$ ) was increased but not significantly in in fast $(2.67 \mathrm{Kg})$ and intermediate $(2.61 \mathrm{Kg})$ compared to slow growing lambs $(2.23 \mathrm{Kg})$.

\subsubsection{The blood profile of $\mathrm{T} 3$ and $\mathrm{T} 4$ hormone}

The blood profile of thyroid hormones (T3 and T4) were not significantly $(\mathrm{P} \leq 0.05)$ different among fast $(1.1 \mathrm{ng} / \mathrm{ml}$ and $8.1 \mu \mathrm{g} / \mathrm{dl})$, intermediate $(0.6 \mathrm{ng} / \mathrm{ml}$ and $12.4 \mu \mathrm{g} / \mathrm{dl})$ and slow $(1.0 \mathrm{ng} / \mathrm{ml}$ and $10.5 \mu \mathrm{g} / \mathrm{dl})$ growing lambs (Table 4).

\subsubsection{The blood profile of total protein}

The total protein profile was not significantly different in fast $(6.53 \mathrm{~g} / \mathrm{dl})$, intermediate $(5.97 \mathrm{~g} / \mathrm{dl})$ and slow $(6.07 \mathrm{~g} / \mathrm{dl})$ growing lambs (Table 4$)$.

\subsubsection{The blood profile of total lipids}

The level of total lipids was not significantly different in fast $(378.0 \mathrm{mg} / \mathrm{dl})$, intermediate (358.0 mg/dl) and slow (392 mg/dl) growing lambs (Table 4).

\subsubsection{The blood profile of glucose level}

The profile of blood glucose was not significantly different in fast $(74.87 \mathrm{mg} / \mathrm{dl})$, intermediate $(75.73 \mathrm{mg} / \mathrm{dl})$ and slow $(74.17 \mathrm{mg} / \mathrm{dl})$ growing lambs (Table 4$)$.

\subsubsection{The blood profile of calcium profile}

The concentration of blood calcium was not significantly different in fast (10.13 $\mathrm{mg} / \mathrm{dl})$, intermediate $(10.0 \mathrm{mg} / \mathrm{dl})$ and slow $(10.87 \mathrm{mg} / \mathrm{dl})$ growing lambs (Table 4$)$.

\subsection{Gene expression profile of selected candidate transcripts}

The expression profile of protein biosynthesis regulating candidate gene (RPL7) was significantly different $(\mathrm{P} \leq 0.05)$ in muscle (Longissmus dorsi) and liver tissues of fast, intermediate and slow growing lambs. While, adipose tissue of intermediate growing had a higher RPL7 expression profile than in fast and slow growing lambs (Figure 2).

The transcript abundance of CPT1 involved in $\beta$-oxidation process was shown to be higher $(P \leq 0.05)$ in muscle, liver samples of fast growing lambs than intermediate growing. In addition, the intermediate growing lambs had greater transcript abundance than slow growing (Figure 3). However, the expression of this gene in fat tissue had similar higher $(\mathrm{P} \leq 0.05)$ in fast and intermediate than slow growing lambs.

Transcript abundance of FABP4 (Lipogenesis) was increased in all body tissues in fast and intermediate compared with slow growing lambs (Figure 4).

The expression of ADIPOQ was higher $(\mathrm{P} \leq 0.05)$ in muscle, liver and fat tissues of fast and intermediate than slow growing lambs (Figure 5). In addition, the adiponectin expression level of muscle collected from fast growing lambs was higher than intermediate growing lambs. 
Table 1. Primer sequences of genes used for quantitative real-time PCR.

\begin{tabular}{|c|c|c|c|}
\hline $\begin{array}{l}\text { Gene } \\
\text { Name }\end{array}$ & $\begin{array}{l}\text { Gene bank acces- } \\
\text { sion number }\end{array}$ & Primer sequence & $\begin{array}{c}\text { Frag- } \\
\text { ment } \\
\text { size } \\
\text { (bp) }\end{array}$ \\
\hline CPT1 & NM_001009259.1 & $\begin{array}{l}\text { F: 5' - TCACCACTACGACCCAGAGG-3' } \\
\text { R: 5'- AGGACTTGTCGAACCACCTG-3' }\end{array}$ & 95 \\
\hline ADIPOQ & KM216385.1 & $\begin{array}{l}\text { F: 5'- TTCCCATTCGCTTTACCAAG-3' } \\
\text { R :5'- CAAGTAGACGGTAATGTGGT-3' }\end{array}$ & 122 \\
\hline FABP4 & NM_001114667.1 & $\begin{array}{l}\text { F: 5' - GCCAGGAATTTGATGAAGTC-3' } \\
\text { R: 5'- ATTTCCCATCCCAGTTTTGT-3' }\end{array}$ & 102 \\
\hline CAPN3 & NM_001009212.1 & $\begin{array}{l}\text { F: 5'- GCCGCAATTTTCCCATTATT-3' } \\
\text { R: 5'- GTAAAACAGGGAGGTCTCG-3' }\end{array}$ & 125 \\
\hline RPL7 & XM_004011739.4 & $\begin{array}{l}\text { F: 5' - AAGCGACTGAGAAAGAAGTT-3' } \\
\text { R: 5'- CTGATGACAAACGCCAATTT-3' }\end{array}$ & 191 \\
\hline GAPDH & NM_001034034.2 & $\begin{array}{l}\text { F: 5' - AGGTCGGAGTGAACGGATTC -3'3 } \\
\text { R: 5'- GGAAGATGGTGATGGCCTTT -3' }\end{array}$ & 219 \\
\hline
\end{tabular}

Abbreviations: PCR, polymerase chain reaction; $b p$, base pair

Table 2. Least square means \pm standard error for growth performance traits of Barki lambs under individually feeding and management system.

\begin{tabular}{|c|c|c|c|c|}
\hline Growth parameters & $\begin{array}{c}\text { Slow grow- } \\
\text { ing }\end{array}$ & $\begin{array}{c}\text { Intermediate } \\
\text { growing }\end{array}$ & Fast growing & $\begin{array}{c}\text { Overall } \\
\text { means }\end{array}$ \\
\hline Birth Wight $(\mathrm{kg})$ & $3.83 \pm 0.2^{\mathbf{a}}$ & $2.82 \pm 0.2^{\mathbf{b}}$ & $4.10 \pm 0.2^{\mathbf{a}}$ & 3.92 \\
\hline Initial body Weight $(\mathrm{kg})$ & $15.8 \pm 1.2^{\mathbf{c}}$ & $22.5 \pm 1.2^{\mathbf{b}}$ & $27.7 \pm 1.2^{\mathbf{a}}$ & 23.27 \\
\hline Final body Weight $(\mathrm{kg})$ & $30.8 \pm 1.8^{\mathbf{c}}$ & $40.7 \pm 1.8^{\mathbf{b}}$ & $49.9 \pm 1.8^{\mathbf{a}}$ & 40.85 \\
\hline Average daily gain $(\mathrm{g})$ & $92.3 \pm 7.4^{\mathbf{b}}$ & $112.0 \pm 7.4^{\mathbf{a b}}$ & $173.6 \pm 7.4^{\mathbf{a}}$ & 118 \\
\hline Total body gain $(\mathrm{kg})$ & $15.0 \pm 1.2^{\mathbf{b}}$ & $18.2 \pm 1.2^{\mathbf{a}}$ & $22.3 \pm 1.2^{\mathbf{a}}$ & 19.2 \\
\hline
\end{tabular}

-Means followed by different superscript letters within the same row are significantly different at $(p<0.05)$. 
Table 3: Least square means \pm standard error for carcass traits of Barki lambs under individually feeding and management system.

\begin{tabular}{|c|c|c|c|c|}
\hline Item & $\begin{array}{c}\text { Slow grow- } \\
\text { ing }\end{array}$ & $\begin{array}{c}\text { Intermedi- } \\
\text { ate growing }\end{array}$ & Fast growing & $\begin{array}{c}\text { Overall } \\
\text { means }\end{array}$ \\
\hline Hot Carcass weight (kg) & $15.10 \pm 1.0^{\mathbf{c}}$ & $19.07 \pm 1.0^{\mathbf{b}}$ & $24.57 \pm 1.0^{\mathbf{a}}$ & $19.46 \pm 1.0$ \\
\hline Dressing Percentage (\%) & $46.90 \pm 0.3$ & $47.48 \pm 0.3$ & $48.83 \pm 0.3$ & $47.70 \pm 0.3$ \\
\hline Non-carcass fat (\%) & $1.18 \pm 0.8$ & $1.21 \pm 0.8$ & $1.46 \pm 0.8$ & $1.22 \pm 0.8$ \\
\hline Liver (kg) & $0.54 \pm 0.2^{\mathbf{a b}}$ & $0.50 \pm 0.2^{\mathbf{b}}$ & $0.62 \pm 0.2^{\mathbf{a}}$ & $0.55 \pm 0.2$ \\
\hline Tail Fat (\%) & $1.48 \pm 0.8$ & 1.790 .34 & 1.650 .34 & 1.740 .34 \\
\hline Total body fat $(\mathrm{kg})$ & $2.23 \pm 0.6$ & $2.61 \pm 0.1$ & $2.67 \pm 0.4$ & 2.57 \\
\hline
\end{tabular}

- Means followed by different superscript letters within the same row are significantly different at $(\mathrm{p}<0.05)$.

- Dressing percentage calculated for slaughter weight.

Table 4. Thyroid hormones, total protein, total lipids glucose and calcium profile (Means \pm stand ard error) of Barki lambs under individually feeding and management system.

\begin{tabular}{|c|c|c|c|c|}
\hline \multicolumn{1}{|l|}{ Item } & $\begin{array}{c}\text { Slow grow- } \\
\text { ing }\end{array}$ & $\begin{array}{c}\text { Intermediate } \\
\text { growing }\end{array}$ & Fast growing & $\begin{array}{c}\text { Overall } \\
\text { means }\end{array}$ \\
\hline $\mathrm{T} 3(\mathrm{ng} / \mathrm{ml})$ & $1.0 \pm 0.2$ & $0.63 \pm 0.2$ & $1.10 \pm 0.2$ & $0.90 \pm 0.2$ \\
\hline $\mathrm{T} 4(\mathrm{ug} / \mathrm{dl})$ & $10.47 \pm 2.1$ & $12.37 \pm 2.1$ & $8.10 \pm 2.1$ & $8.49 \pm 2.1$ \\
\hline Total protein $(\mathrm{g} / \mathrm{dl})$ & $6.07 \pm 0.8$ & $5.97 \pm 0.2$ & $6.53 \pm 0.2$ & 6.22 \\
\hline Total Lipids $(\mathrm{mg} / \mathrm{dl})$ & $392 \pm 11.5$ & $358 \pm 48.8$ & $378 \pm 16.4$ & 390 \\
\hline Glucose $(\mathrm{mg} / \mathrm{dl})$ & $74.17 \pm 0.8$ & $75.73 \pm 0.6$ & $74.87 \pm 2.3$ & 72.29 \\
\hline Calcium $(\mathrm{mg} / \mathrm{dl})$ & $10.87 \pm 2.2$ & $10.0 \pm 1.3$ & $10.13 \pm 1.3$ & 11.42 \\
\hline
\end{tabular}




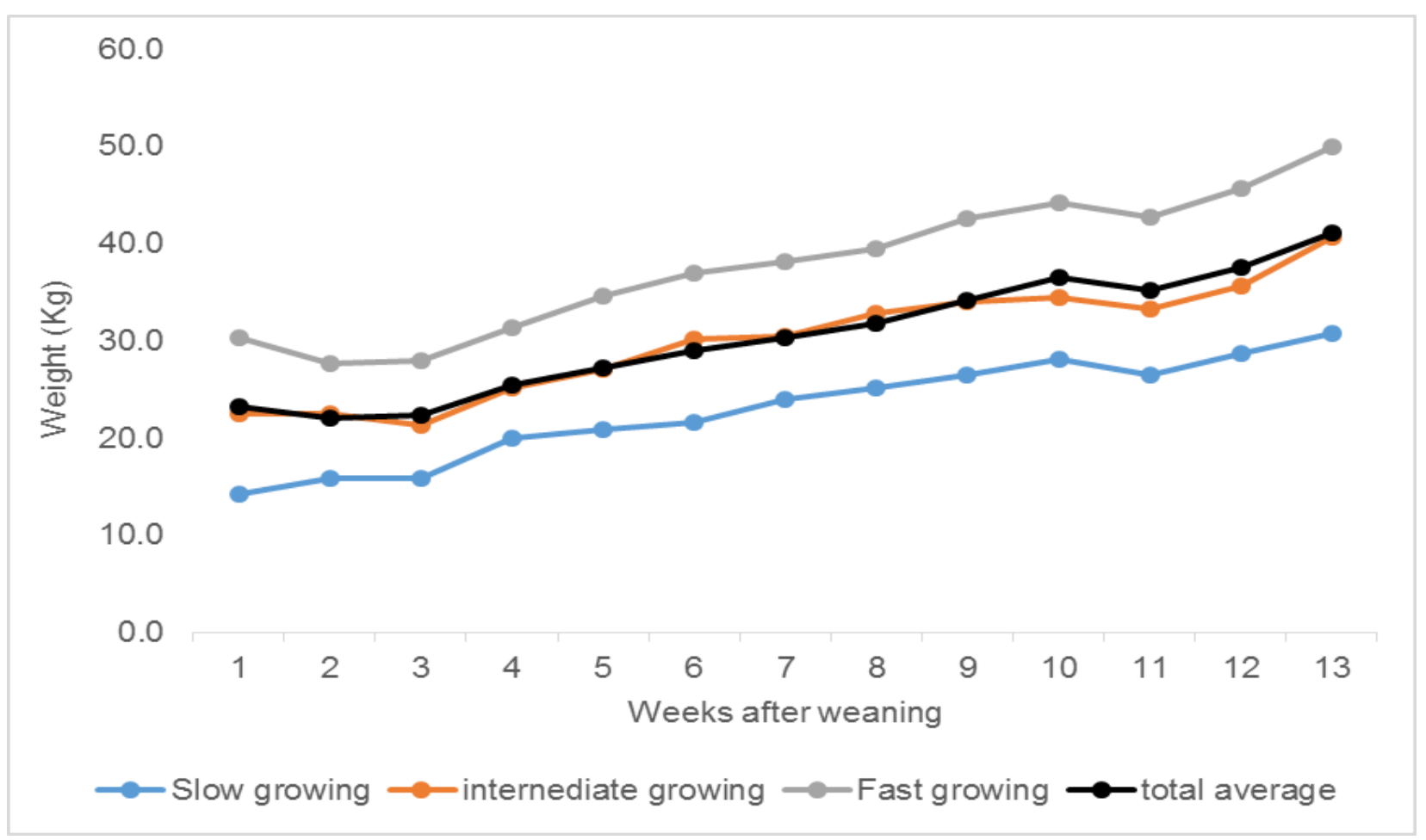

Figure 1. Growth rate of Barki lamb varied in growth performance under individually feeding and management system.

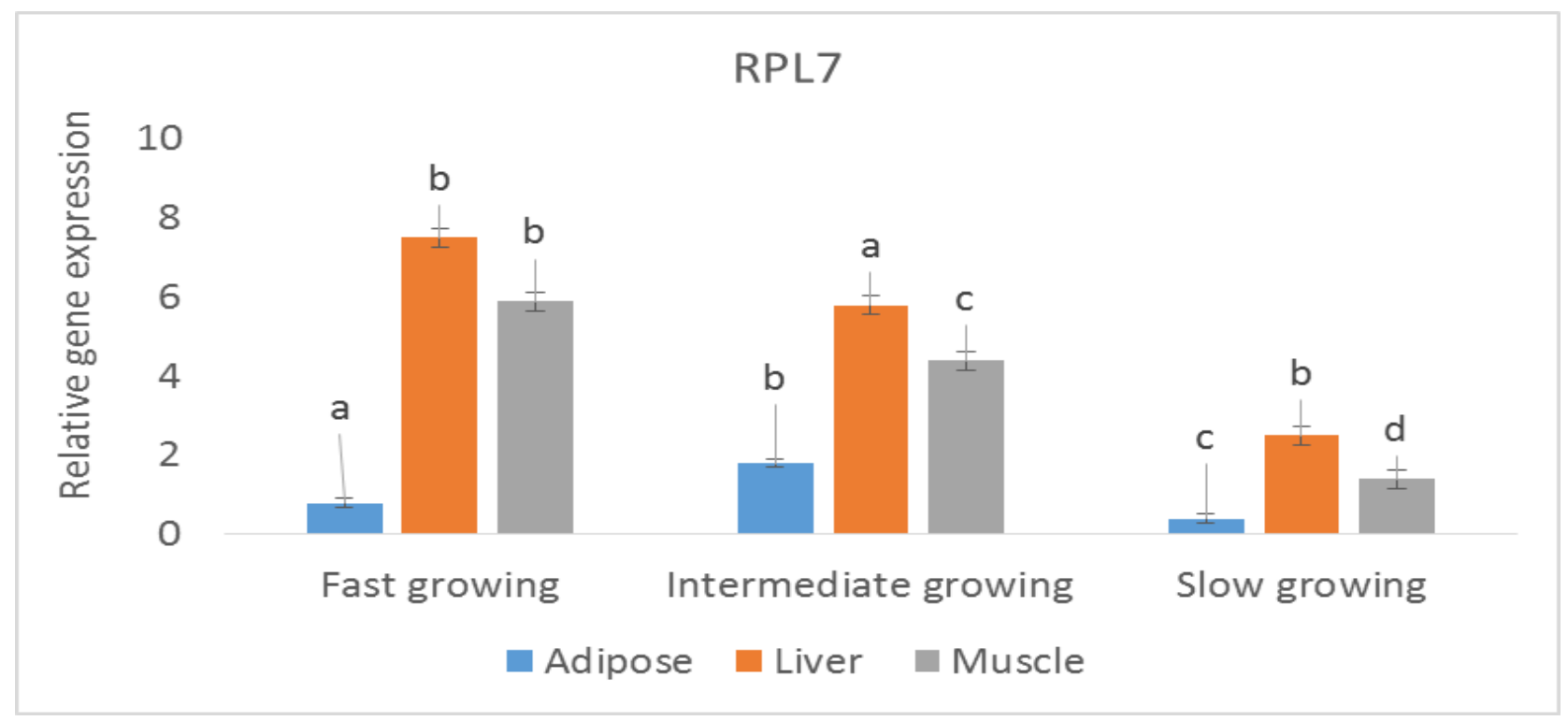

Figure 2. Expression profile of protein biosynthesis gene (RPL7) in different body tissues of Barki lambs varied in growth performance under individually feeding and management system. 


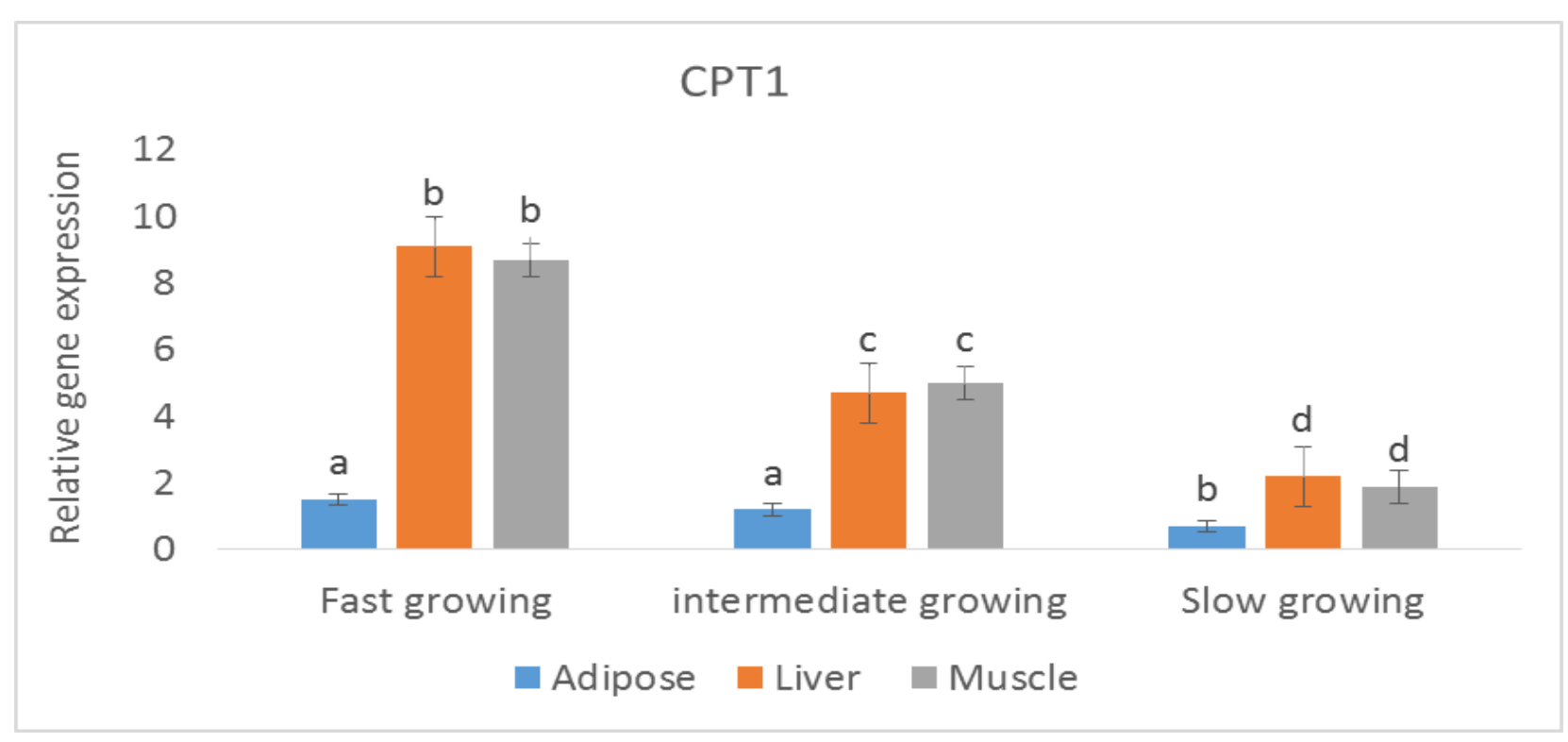

Figure 3. Expression profile of lipolysis gene (CPT1) in different body tissues of Barki lambs varied in growth performance under individually feeding and management system.

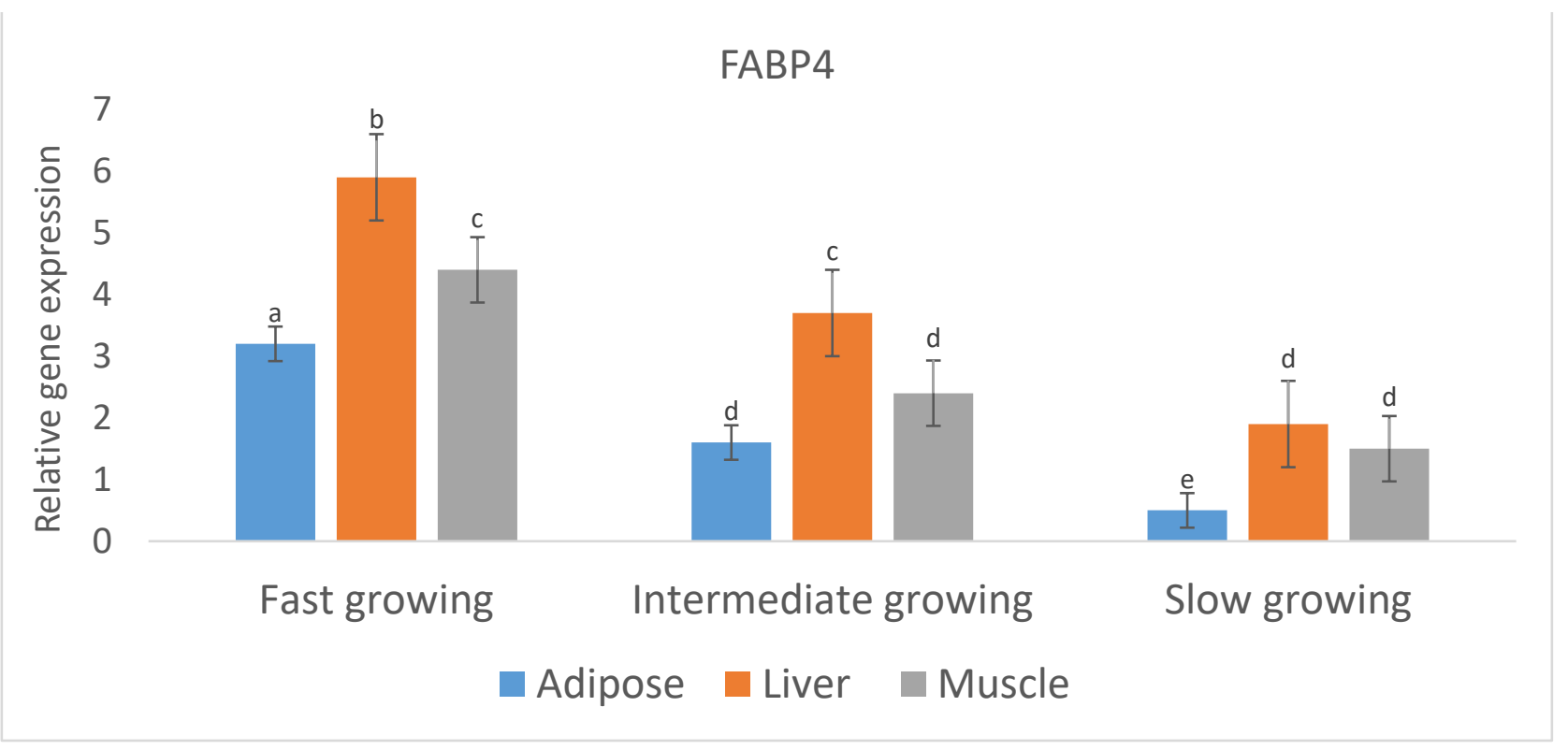

Figure 4. Expression profile of lipogenesis gene (FABP4) in different body tissues of Barki lambs varied in growth performance under individually feeding and management system. 


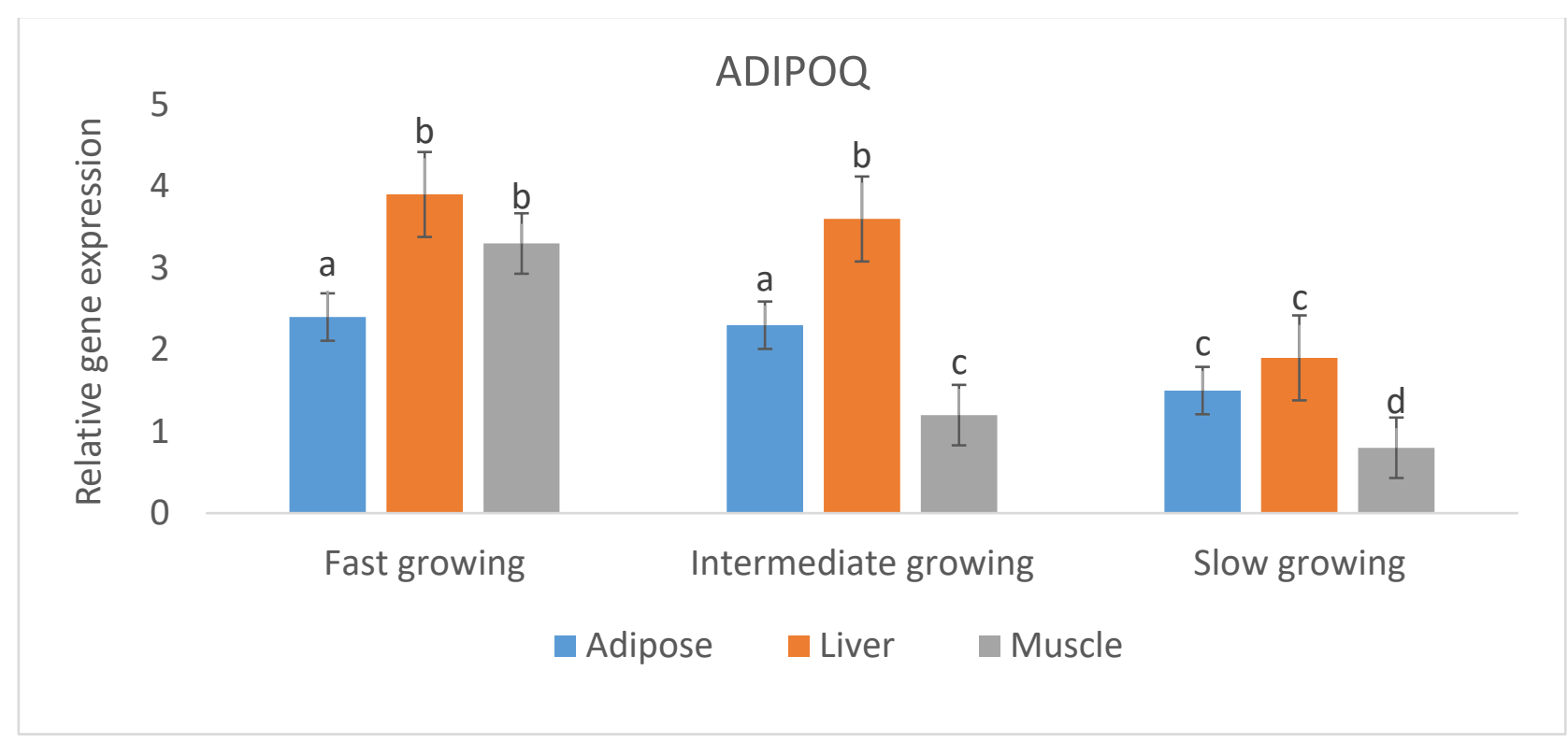

Figure 5. Expression profile of lipogenesis gene (ADIPOQ) in different body tissues of Barki lambs varied in growth performance under individually feeding and management system.

\section{CAPN3}
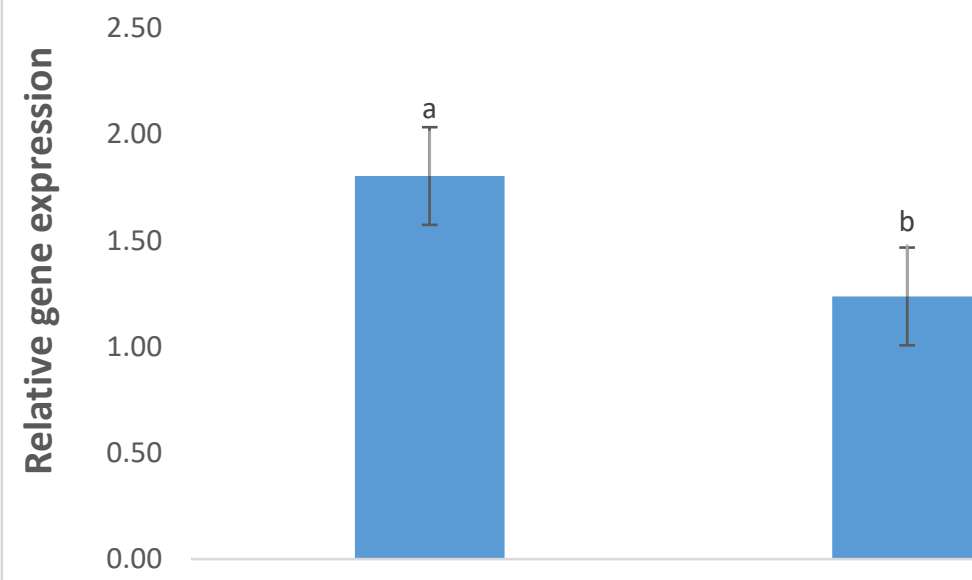

Fast growing

Intermediate growing

Slow growing

Figure 6. Expression profile CAPN3 in muscle of Barki lambs) in muscle of Barki lambs varied in growth performance under individually feeding and management system. 


\section{Discussion}

The availability of sheep feed is not stable in terms of both quantity and quality particularly in the subtropical region. Therefore, it is a privilege to select animals that recorded fast grow rate for meat production [3]. In lamb production system, the growth rate prior to weaning is considered a vital factor in the determination of system performance, as fast growing lambs, that quickly reaches slaughter weight, will proportionately reduce the maintenance cost. In the current study, initial body weight of fast growing lambs was greater than those intermediate and slow growing lambs, which were positively linked with increased final body weight in fast growing lambs. The total and average daily body gain were increased $(\mathrm{P} \leq 0.05)$ in fast growing lambs $(22.3 \mathrm{Kg}$ and $173.6 \mathrm{gm})$ compared to intermediate (18.2 Kg and $112.0 \mathrm{gm}$ ) and slow growing lambs (15.0 Kg and $92.3 \mathrm{gm})$. The growth rate of Awassi lambs were increased than Washera and Wollo highland breeds reflecting the body weight gain genetic potentiality among these three breeds [4]. The increased body gain was the reflected in heavier final body weight of fast growing animals $(49.9 \mathrm{Kg})$ compared to intermediate $(40.7 \mathrm{Kg})$ and slow growing groups $(30.8 \mathrm{Kg})$. The average body weight of Egyptian breeds is approximately $51 \mathrm{~kg}$ in Ossimi, $53 \mathrm{~kg}$ in Rahmani and $44 \mathrm{~kg}$ in Barki at marketing age [11,12, 21-25].

The biogenesis of ribosome and translation of protein are essential for the cells' growth, differentiation, proliferation and the animal development [26]. The building of muscle fibers and synthesis of protein required for animal growth is regulated partially by ribosomal gene activity when proper nutrition is (provided [27]. Indeed, the synthesis rate of muscle protein is mainly dependent on the content of ribosomes in muscle fibers [28]. The expression profile of protein biosynthesis candidate gene (RPL7) was greater significantly in muscle (Longissmus dorsi) and liver tissues of fast and intermediate growing lambs than in slow growing lambs which is in line with increased body mass of fast and intermediate growing lambs. Indeed, ribosomal proteins have a direct regulatory effect on the synthesis of protein in different animal species [29, 30, 31]. It was found that the RPL7 was down-regulated in the broilers liver during feed restriction while in the adipose tissue there was no detection of differential expression [31]. It was also reported that the genes involved in protein are altered severely due to diet restriction in porcine skeletal muscle $[29,30]$. Sheep genome-wide study proposed RPL7 as candidate gene associated with growth performance and meat production traits [17]. Additionally, RPL7 was linked with pre-weaning gain in German mutton merino [10]. Noteworthy, our data indicated higher expression profile of this gene in muscle and liver tissues compared to adipose tissue. While, Thorrez et al., [32] have demonstrated increased expression of RPL3 in adipose and muscle tissues compared to liver of human cells. This spatiotemporal variation between species and tissues reflect changing of the content and activity of ribosome protein biosynthesis during different phases of body growth. In support of this idea, Cassar-Malek et al., [33] indicated a change in the expression of ribosomal protein genes during different time points of bovine semitendinosus muscle development in prenatal fetus stage.

The increasing in body mass of fast and intermediate than the slow growing lambs was resulting from a higher expression of Calpain3 (CAPN3) gene. This result may be linked with the ability of each group growth rate. Calpains (CAPN) encodes cysteine-activated intracellular proteases associated with an increased number of myoblasts by controlling mitotic cycle [34, 35]. Indeed, sheep had TT genotype of CAPN had heavier birth weight, final body weight and average daily gain those with other genotype, while CC genotype recorded the lowest values of these traits [36]. In support to the potential role of CAPN3 in enhancing sheep body weight, several studies have demonstrated its genetic association with sheep growth performance and meat production traits [37-39]. Therefore, it could be revealed that ribosomal and calpain encoded genes are co-expressed to enhance sheep body mass by enhancing myoblast proliferating activity and protein accumulation independent of the hormonal profile of thyroid hormones. Although, increased plasma T4 concentration was recorded in Suffolk ewes compared to Gulf Coast native 
ewes, which was positively linked with larger body size and improved growth performance [40].

The increased body growth required high-energy demand. In this regard, fatty acids are metabolized by oxidation pathway in mitochondria to give acetyl-CoA, which is completely broken down via the Krebs cycle, or converted into acetate as an energy source [41]. Indeed, approximately 4-30 \% of circulating acetate and 10-55 \% of beta-hydroxybutyrate may be derived from hepatic oxidation of long chain fatty acids in cattle [42] (Mery et al., 1992). The catabolism of fatty acid occurred in the mitochondria by $\beta$-oxidation pathway [43]. Our results demonstrated that the transcript abundance of CPT1 involved in $\beta$-oxidation process was shown to be higher in muscle, liver samples of fast growing lambs than intermediate and slow growing lambs; additionally the intermediate growing lambs had greater transcript abundance than slow growing lambs. While, fast and intermediate growing lambs had similar expression of this gene in fat tissue, but both had higher expression than slow growing lambs. A study that has been done in the fetal rabbit shown that cultured hepatocytes with long chain fatty acids increased CPT I expression [44]. The up-regulation of this gene in fast growing lambs may be due to increased metabolic demand to meet accelerated growth performance in fast and intermediate growing lambs which dependent on the utilization of fatty acids in both liver and developing muscle fibers. In support of this idea, Price et al., [45] reported a 10-fold increase in the expression of mRNA encoding CPT1B in lactating ewes compared to late pregnancy and control mammary gland cells. In addition, down regulation of CPT1b reduced fatty acid metabolism and subsequently resulted in obesity of rats [46] (Warfel et al., 2017).

Bionaz et al., [47] indicated that Madin-Darby bovine kidney cells (MDBK) increased long chain fatty acid oxidation through greater enhanced transport of FABP4 gene into cytoplasm in addition to CPT1A in the mitochondria, which was revealed by up regulation of these genes that leading to the synthesis of TAG and cholesterol are under the control of PPAR- $\alpha$. Transcript abundance of FABP4 was increased in all examined body tissues in fast and intermediate growing compared with slow growing lambs. A genetic SNP inFABP4 gene was associated with meat tenderness in sheep [18] The data of study strongly support the idea that oxidation of long chain fatty acid oxidation is a key determining molecular mechanism explaining the variation of sheep growth performance. Additionally, the transcript abundance of ADIPOQ was higher in muscle, liver and fat tissues of fast and intermediate growing than slow growing lambs. Moreover, the adiponectin expression level of muscle collected from fast growing was higher than intermediated growing lambs.

Adipokines have an important biological role in regulating lipid metabolism [48]. The transcript abundance of ADIPOQ was higher in muscle, liver and fat tissues of fast and intermediate growing than those of slow growing lambs. In addition, the adiponectin expression level of muscle collected from fast growing was higher than intermediated growing lambs. They found that fat ADIPOQ mRNA expression (1 week after calving) had a positive correlation with free fatty acid so, the mobilization of body reserves [49]. Another study was done on New Zealand Romney lambs, where they reported an association between the growth and carcass traits and the ADIPOQ haplotypes [50]. This supports that the fast-growing sheep and the intermediate growing sheep both had a higher growth as they had higher levels of expression of the ADIPOQ gene. Moreover, a genomic variant (SNP) ADIPOQ were associated with marbling score of Hanwoo cattle [51, 52]. Therefore, this study suggested that ADIPOQ gene in addition to its role in regulating deposition and differentiation of fat in the cattle it could be used to differentiate sheep with varied grow and carcass traits.

\section{Conclusions}

The data of the current investigation indicated a link between variation in gene expression profile in main body tissues and growth performance in addition carcass traits 
of Barki lambs in Egypt. Which could be induced by the genetic makeup independent of the levels of thyroid hormones, however, this hypothesis required a large population for validation. In addition, the transcriptional profile of CPT1, FABP4, RPL7 and CAPN3 are linked with growth performance also carcass traits of lambs, providing an evidence for the importance of co-expression of these genes in different body tissues involved in this process.

\section{Author Contributions:}

All authors have contributed equally to the design of the study, farm work and revising the manuscript. N.G has done the expression profile experiment and wrote the manuscript.

\section{Funding:}

This work was funded by The Science, Technology \& Innovation Funding Authority (STDF), Egypt for the project with ID: Agri 326.

\section{Conflicts of Interest:}

All authors confirm that there is no any conflict of interest that jeopardize this investigation.. 


\section{References}

1. Elshazly, A.G.; Youngs C.R. Feasibility of utilizing advanced reproductive technologies for sheep breeding in Egypt. Part 1. Genetic and nutritional resources. Egyptian Journal of Sheep and goat Sciences 2019, 14: 39-52.

2. El-Wakil, S.; Manal Elsayed. Genetic, phenotypic and environmental trends towards improving body weight in Barki sheep Egyptian Journal of Sheep and goat Sciences 2013, 8: 1-510.

3. Parker, W.J.; McCutcheon, S.N.; Wickham, G.A. Effect of administration and ruminal presence of chromic oxide controlled release capsules on herbage intake of sheep. New Zealand Journal of Agricultural Research (NZJAR), 1991; 34:193200.

4. Moghaddam, V.K.; Elahi, M.Y.; Nasri, M.H.F.; Elghandour, M.M.M.Y.; Monroy, J.C.; Salem, A.Z.M.; Karami, M.; Mlambo, V. Growth performance and carcass characteristics of finishing male lambs fed barberry pomace-containing diets. Animal Biotechnology 2021, 32 :178-184. doi: 10.1080/10495398.2019.1674861.

5. Lupi, T.M.; Nogales, S.; León, J.M.; Barba, C.; Delgado, J.V.; Characterization of commercial and biological growth curves in the Segureña sheep breed. Animal 2015, 9: 1341-1348. doi: 10.1017/S1751731115000567.

6. Alemneh, T.; Getabalew, M.. Factors Influencing the Growth and Development of Meat Animals. International Journal of Animal Science 2019, 3: 1-5.

7. Yilmaz, O.; Denk, H.; Bayram, D. Effects of lambing season, sex and birth type on growth performance in Norduz lambs. Small Ruminant Research 2007, 68: 336-339.

8. Kefelegn, K.; Mekonnen, T.; Girma, A.; Goetsch AL. Analysis of Growth Performance Data in Sheep using Linear Mixed Model. World Jouenal of Agriculture and Soil Sciences 2019, $2: 1-5$.

9. Massender, E.; Brito, L.F.; Cánovas, A.; Baes, C.F.; Kennedy, D.; Schenkel, F.S. A genetic evaluation of growth, ultrasound, and carcass traits at alternative slaughter endpoints in crossbred heavy lambs. Journal of Animal Science 2019,97 :521-535. doi: 10.1093/jas/sky455.

10. Wang, H.; Zhang, L.; Cao, J.; Wu, M.; Ma, X.; Liu, Z.; Liu, R.; Zhao, F.; Wei, C.; Du, L. Genome-Wide Specific Selection in Three Domestic sheep breeds. PLoS One 2015, 10: e0128688. doi: 10.1371/journal.pone.0128688.

11. Ashour, G.; Gad, A.; Fayed, A.K., Ashmawy, N.A.; El- Sayed, A. Evaluation of growth performance, blood metabolites and gene expression analysis in Egyptian sheep breeds, in relation to age. World Veterinary Journal 2020, 10: 18-29. DOI: https://dx.doi.org/10.36380/scil.2020.wvj3

12. Miao, X.; Luo, Q.; Qin, X. Genome-wide analysis reveals the differential regulations of mRNAs and miRNAs in Dorset and Small Tail Han sheep muscles. Gene 2015, 562, 188-196. doi: 10.1016/j.gene.2015.02.070.

13. Chao, T.; Wang, G.; Wang, J.; Liu, Z.; Ji, Z.; Hou, L.; Zhang, C. Identification and classification of new transcripts in dorper and small-tailed han sheep skeletal muscle transcriptomes. PLoS One 2016, 11:e0159638. DOI: 10.1371/journal.pone.0159638

14. Sun, L.; Bai, M.; Xiang, L.; Zhang, G.; Ma, W.; Jiang, H. Comparative transcriptome profiling of longissimus muscle tissues from Qianhua Mutton Merino and Small Tail Han sheep. Scientific Report 2016, 6:33586. doi: 10.1038/srep33586

15. Zhang, C.; Wang, G.; Wang, J.; Ji, Z.; Liu, Z.; Pi, X.; Chen, C. Characterization and comparative analyses of muscle transcriptomes in Dorper and small-tailed Han sheep using RNA-Seq technique. PLoS One 2013, 8:e72686. DOI: 10.1371/journal.pone.0072686

16. Zhang, C.; Wang, G.; Hou, L.; Ji, Z.; Wang, J. De novo assembly and characterization of the skeletal muscle transcriptome of sheep using Illumina paired-end sequencing. Biotechnology Letters 2015, 37: 1747-56. doi: 10.1007/s10529-0151854-9.

17. Zhang, L.; Liu, J.; Zhao, F.; Ren, H.; Xu, L.; Lu, J.; Zhang, S.; Zhang, X.; Wei, C.; Lu, G.; Zheng, Y.; Du, L. Genomewide association studies for growth and meat production traits in sheep. PLoS One 2013, 8:e66569. doi: 10.1371/journal.pone.0066569.

18. Xu, Q.L.; Tang G.W.; Zhang Q.L.; Huang Y.; KLiu., Y.X.; Quan K.; Zhu K.Y.; Zhang C.X. The FABP4 gene polymorphism is associated with meat tenderness in three Chinese native sheep breeds. Czech J. Anim. Sci., 56, 2011 (1): 1-6.

19. Frild, R.A.; Kemp, J.D.; and Varney, W.Y. Indices for lamb carcass composition. Journal of Animal Science 1961, 322: 218.

20. Ghanem, N.; Ahmed, D.A.R.; Dessouki, S.M.; Faheem, M.S.; Gad, A.Y.; Peippo, J.; Barkawi, A.H. Cellular and molecular alterations of buffalo oocytes cultured under two different levels of oxygen tension during in vitro maturation. Zygote, 2021, 24:1-11. doi: 10.1017/S0967199420000945.

21. Almahdy, H.; Tess, M.W.; El-Tawil, E.; Shehata, E.; Mansour, H. Evaluation of Egyptian sheep production systems: II. Breeding objectives for purebred and composite breeds. Journal of Animal Science 2000, 78: $288-295$. doi:10.2527/2000.782283x. 
22. El-Malky, O.M.; Mostafa, T.H.; Ibrahim, N.H.; Younis, F.E.; Abd El-Salaam, A.M.; Tag El-Din, H.A. Comparison between productive and reproductive performance of Barki and Ossimi ewes under Egyptian conditions. Egyptian Journal of Sheep \& Goat Sciences 2019, 14: 61-82.

23. Hassan, T.M.M. Effects of weaning age and some other factors on growth performance of Ossimi lambs. Egyptian Journal of Sheep \& Goat Sciences 2017, 12: 29:38.

24. Khalifa, A.I.; Ahmed, M.E.; Hafez, Y.H.; El-Zolaky, O.A.; Bahera, K.M.; Abido, A.A. Age at puberty and fertility of Rahmani sheep fed on biological inoculated corn silage. Annals of Agricultural Science 2013, 58: 163-172.

25. Marai, I.F.M.; Daader, A.H.; Bahgat, L.B. Performance traits of purebred Ossimi and Rahmani lambs and their crosses with Finnsheep born under two accelerated mating systems. Archives Animal Breeding 2009, 52: 497-511.

26. Zhou, X.; Liao, W.J.; Liao, J.M.; Liao, P.; Lu,H. Ribosomal proteins: functions beyond the ribosome. Journal of Molecular Cell Biology 2015, 7: 92-104. doi: 10.1093/jmcb/mjv014.

27. Nader, G.A.J. Ribosomes ‘muscle up' postnatal muscle growth. Journal of Physiology 2014, 592: 5143. doi: 10.1113/jphysiol.2014.284828.

28. Millward, D.J.; Garlick, P.J.; James, W.P.; Nnanyelugo, D.O.; Ryatt, J.S. Relationship between protein synthesis and RNA content in skeletal muscle. Nature 1973, 241: 204-205.

29. Costa, N.D.; Mcgillivray, C.; Bai, Q.; Wood, J.D.; Evans, G.; Chang, K.C. Restriction of dietary energy and protein induces molecular changes in young porcine skeletal muscles. The journal of Nutrition 2004, 134: 2191-2199. doi: 10.1093/jn/134.9.2191.

30. Han, E.S.; Hickey, M. Microarray Evaluation of Dietary Restriction. The Journal of Nutrition 2005, 135: $1343-1346$.

31. Wang, J.; Chen, W.; Kang, X.; Huang, Y.; Tian, Y.; Wang, Y. Identification of differentially expressed genes induced by energy restriction using annealing control primer system from the liver and adipose tissue of broilers. Poultry Science 2012, 91: 972-978. doi: 10.3382/ps.2011-01949.

32. Thorrez, L J.; Van Deun, K J.; Tranchevent, L.C J.; Van Lommel, L J.; Engelen, K J.; Marchal, K J.; Moreau, Y J.; Van Mechelen, I J.; Schuit, F. Using Ribosomal Protein Genes as Reference: A Tale of Caution. PLoS One 2008, 3: e1854. doi: 10.1371/journal.pone.0001854.

33. Cassar-Malek, I.; Passelaigue, F.; Bernard, C.; Leger, J.; Hocquette, J.F. Target genes of myostatin loss-of-function in muscles of late bovine fetuses. BMC Genomics 2007, 8:63. doi: 10.1186/1471-2164-8-63.

34. Barnoy, S.; Glaser, T.; Kosower, N.S. Calpain and calpastatin in myoblast differentiation and fusion effects of inhibitors. Biochim Biophys Acta 1997, 1358: 181-188. doi: 10.1016/s0167-4889(97)00068-2.

35. Cottin, P.; Brutis, J.J.; Poussard, S.; Elamrani, N.; Broncard, S.; Ducastaing, A. Ca2_-dependent proteinases (calpains) and muscle cell differentiation. Biochim Biophys Acta 1994, 1223: 170-178. doi: 10.1016/0167-4889(94)90223-2.

36. Mahrous, K.F.; Hassanane, M.S.; Shafey, H.I.; Abdel Mordy, M.; Rushdi, H.E. Association between single nucleotide polymorphism in ovine Calpain gene and growth performance in three Egyptian sheep breeds. Journal of Genetic Engineering Biotechnology 2016, 14: 233-240. doi: 10.1016/j.jgeb.2016.09.003.

37. Koohmaraie M. Ovine skeletal muscle multicatalytic proteinase complex (proteasome): purification, characterization, and comparison of its effects on myofibrils with mu-calpains. Journal of Animal Science 1992; 70: 3697-3708. doi: 10.2527/1992.70123697x.

38. Nassiry, M.R.; Shahroudi, F.E.; Tahmoorespur, M.; Javadmanesh, A. Genetic variability and population structure in beta-lactoglobulin, calpastatin and calpain loci in Iranian Kurdi sheep. Pak. J. Biol. Sci. 2007; 10: 1062-1067. doi: 10.3923/pjbs.2007.1062.1067.

39. Naveen, K.S.; Jayashankar, M.R.; Nagaraja, R.; Nagaraja, C.S.; Nadeem, F.; Satyanarayana, K. Genetic polymorphism of ovine Calpine gene in Bander sheep. International Journal of Scienticic Environmental Technology 2015; 4: 804-812.

40. Williams, C.C.; Calmes, K.J.; Fernandez, J.M.; Stanley, C.C.; Lovejoy, J.C.; Bateman, H.G.; Gentry, L.R.; Gantt, D.T.; Harding, G.D. Glucose metabolism and insulin sensitivity in Gulf Coast native and Suffolk ewes during late gestation and early lactation. Small Ruminant Research 2004, 54: 167-171. doi.org/10.1016/j.smallrumres.2003.11.007

41. Guzman, M.; Geelen, M.J.H. Regulation of fatty acid oxidation in mammalian liver. Biochim. Biophys. Acta 1993, 1167: 227-241. doi: 10.1016/0005-2760(93)90224-w.

42. Mery, R.S.; Liesman, J.S.; Herdt, T.H. Metabolism of long-chain fatty acids by ruminant liver. Journal of Nutrion 1992 , 122: 832-837. doi: 10.1093/jn/122.suppl_3.832.

43. Sun, H.Z.; Zhou, M.; Wang, O.; Chen, Y.; Liu, J.X.; Guan, L.L. Multi-omics reveals functional genomic and metabolic mechanisms of milk production and quality in dairy cows. Bioinformatics 2020, 36: 2530-2537. doi: 10.1093/bioinformatics/btz951.

44. Prip-Buus, C.; Thumelin, S.; Chatelain, F.; Pegorier, J.P.; Girard, J. Hormonal and nutritional control of liver fatty acid oxidation and ketogenesis during development. Biochem. Soc. Trans 1995, 23: 500-506. doi: 10.1042/bst0230500.

45. Price, N.T.; Jackson, V.N.; van der Leij, F.R.; Cameron, J.M.; Travers, M.T.; Bartelds, B.; Huijkman, N.C.; Zammit, V.A. Cloning and expression of the liver and muscle isoforms of ovine carnitine palmitoyltransferase 1: residues within the N-terminus of the muscle isoform influence the kinetic properties of the enzyme. Biochem J. 2003, 372 : 871-879. doi: 10.1042/BJ20030086. 
46. Warfel, J.D.; Vandanmagsar, B.; Dubuisson, O.S.; Hodgeson, S.M.; Elks, C.M.; Ravussin, E.; Mynatt ,R.L. Examination of carnitine palmitoyltransferase 1 abundance in white adipose tissue: implications in obesity research. Am J Physiol Regul Integr Comp Physiol. 2017, 312: R816-R820. doi: 10.1152/ajpregu.00520.2016.

47. Bionaz, M.; Thering, B.J.; Loor, J.J. Fine metabolic regulation in ruminants via nutrient-gene interactions: saturated longchain fatty acids increase expression of genes involved in lipid metabolism and immune response partly through PPAR$\alpha$ activation. British Journal of Nutrtion 2012, 107: 179-91. doi: 10.1017/S0007114511002777.

48. Reynolds, C.M.; Vickers, M.H. The role of adipokines in developmental programming: evidence from animal models. Journal of Endocrinology 2019, 242: T81-T94. doi: 10.1111/apha.12223.

49. Elis, S.; Coyral-Castel, S.; Freret, S.; Cognié, J.; Desmarchais, A.; Fatet, A.; Rame, C.; Briant, E.; Maillard, V.; Dupont, J. Expression of adipokine and lipid metabolism genes in adipose tissue of dairy cows differing in a female fertility quantitative trait locus. Journal of Dairy Science 2013; 9: 7591-602. doi: 10.3168/jds.2013-6615.

50. An, Q.; Zhou, H.; Hu, J.; Luo, Y.; Hickford, J.G.H. Haplotypes of the Ovine Adiponectin Gene and Their Association with Growth and Carcass Traits in New Zealand Romney Lambs. Genes (Basel). 2017, 8: 160. doi: 10.3390/genes8060160.

51. Shin, S.; Chung, E. Novel SNPs in the bovine ADIPOQ and PPARGC1A genes are associated with carcass traits in Hanwoo (Korean cattle). Molecular Biology Report 2013, 40: 4651-60. doi: 10.1007/s11033-013-2560-0.

52. Choi, Y.; Davis, M.E.; Chung, H. Effects of genetic variants in the promoter region of the bovine adiponectin (ADIPOQ) gene on marbling of Hanwoo beef cattle. Meat Science 2015, 105: 57-62. doi: 10.1016/j.meatsci.2015.02.014. 